\title{
LUPUS SCIENCE\& MEDICINE \\ Impact of COVID-19 pandemic on SLE: beyond the risk of infection
}

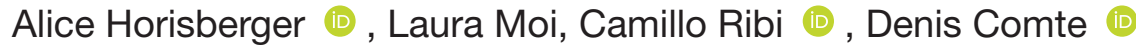

To cite: Horisberger A, Moi L, Ribi C, et al. Impact of COVID-19 pandemic on SLE: beyond the risk of infection. Lupus Science \& Medicine 2020;7:e000408. doi:10.1136/ lupus-2020-000408

Received 21 April 2020 Accepted 24 April 2020

Check for updates

(C) Author(s) (or their employer(s)) 2020. Re-use permitted under CC BY-NC. No commercial re-use. See rights and permissions. Published by BMJ.

Service of Immunology and Allergy, Departement de medecine, Centre hospitalier universitaire vaudois, Lausanne, Switzerland

Correspondence to

Dr Denis Comte; denis.comte@ chuv.ch
Dear editor,

The rapidly expanding coronavirus disease 2019 (COVID-19) is a global health challenge and a source of anxiety amplified by the constant news stream. The mortality rate from COVID-19 is difficult to establish given the heterogeneity of reports and confounding factors such as difference in healthcare systems around the world. The occurrence of severe acute respiratory distress syndrome (ARDS) and mortality are increased in the elderly and in patients with underlying conditions such as cardiovascular disease and chronic respiratory conditions. To date, neither autoimmune diseases nor immunosuppressants appear to be risk factors for serious complications associated with COVID-19. Transplant patients taking immunosuppressants do not appear more prone for severe COVID-19. ${ }^{1}$ In this unprecedented time, we must find the safest balance between protective measures by physical distancing and ensuring the best standards of care for patients with SLE.

SLE is an autoimmune disease prone to flare-ups that are linked to significant morbimortality. Immunosuppression-related infections are one of the leading causes of premature death in patients with SLE. However, there are currently no data to support a higher infection rate, an increased risk of ARDS or other serious complications related to COVID-19. One could even argue that SLE and/or its treatment can protect against the serious complications related to COVID-19. Current knowledge of the immunopathology of COVID-19 is far too limited to draw definitive conclusions, but certain hypotheses can be made on the basis of preliminary data and previous epidemics of coronavirus.

Variability in illness severity in patients with COVID-19 highlights a complex interaction between virological factors and host susceptibility. ARDS is the most frequent cause of death of COVID-19. It is related to an excessive host immune response to the virus, characterised by a cytokine storm with features of macrophage activation syndrome (MAS) and cytokine-release syndrome (CRS). ${ }^{2}$ There is evidence showing that immunosuppressants and, in particular, cytokine-targeted biological and glucocorticoids can hamper the inflammatory response and improve the outcome of patients with MAS or CRS. ${ }^{3}$ Currently, various clinical trials are underway to study the optimal approach to reduce the inadequate inflammatory response with immunosuppressants to prevent ARDS in COVID-19.

Severe acute respiratory syndrome coronavirus 2 (SARS-CoV-2) uses the ACE 2 as a receptor for host cell entry. A recent publication suggested that the ACE2 gene is demethylated and overexpressed in $\mathrm{T}$ cells from patients with SLE compared with healthy controls. ${ }^{4}$ Data on ACE2 expression in pulmonary epithelial cells of patients with SLE or on ACE2 gene polymorphisms in this population are lacking.

Type 1 interferons (IFNs) are cytokines that play a key role in antiviral immunity and include among others IFN- $\alpha$ and IFN- $\beta$. Type 1 IFN interfere with coronavirus replication in vitro. SARS-CoV, and probably also SARS-CoV-2, interfere with the host's antiviral signalling pathways, resulting in decreased production of type I IFN. ${ }^{5}$ The efficacy and safety of IFN- $\beta 1$ in COVID-19 are currently evaluated as part of the 'Solidarity' clinical trial. Overexpression of type I IFN is one of the characteristics of SLE and appears to be the result of genetic polymorphisms and environmental factors. One may hypothesise that the increased bioavailability of type 1 IFN in SLE promotes host defenses against SARS-CoV2 infection and provide some degree of protection against severe COVID-19 in this patient population.

Given their antiviral effect against SARS-CoV-2 in vitro, antimalarials (hydroxychloroquine and chloroquine) represent a potential adjunct treatment for patients with COVID-19 infection. Small uncontrolled or poorly controlled clinical trials have shown an antiviral effect of antimalarials in COVID19 
contributing to the growing interest of the health authorities, media and general population. As a result, concerns have arisen about the availability of antimalarials for patients with SLE, for whom these drugs have been proven for a long time. Since only limited data support the use of these drugs in COVID-19, a recent document emphasised the importance of limiting their systematic use in COVID-19 and rationing the supply available for clinical trials and for patients with SLE or with other rheumatic diseases. ${ }^{6}$

During the current COVID-19 pandemic, strict measures of social distancing have been implemented and are probably the best way to limit the spread of the virus. However, since the healthcare system is overwhelmed by COVID-19 cases and regular patients are advised not to leave their confinement for elective consultation, we must remain alert to the risk of missed or delayed diagnosis of SLE flare-up. Therefore, regular monitoring should be maintained for the early detection of disease flare-up. ${ }^{7}$ With the aim to reduce contact exposure, telephonic visits are a reasonable first-step screening for stable patients, nevertheless faceto-face visit should not be precluded for SLE patients with active disease potentially requiring therapeutic changes.

COVID-19 pandemic is changing our approach to clinical surveillance and management. In the absence of recommendations, we underline the importance to adapt the medical follow-up of patients with SLE on a case-by-case basis.

Contributors Authors have contributed equally to this manuscript.

Funding The authors have not declared a specific grant for this research from any funding agency in the public, commercial or not-for-profit sectors.
Competing interests None declared.

Patient consent for publication Not required.

Provenance and peer review Not commissioned; internally peer reviewed.

Open access This is an open access article distributed in accordance with the Creative Commons Attribution Non Commercial (CC BY-NC 4.0) license, which permits others to distribute, remix, adapt, build upon this work non-commercially, and license their derivative works on different terms, provided the original work is properly cited, appropriate credit is given, any changes made indicated, and the use is non-commercial. See: http://creativecommons.org/licenses/by-nc/4.0/.

ORCID iDs

Alice Horisberger http://orcid.org/0000-0002-3732-8662

Camillo Ribi http://orcid.org/0000-0002-0446-9741

Denis Comte http://orcid.org/0000-0002-6605-1498

\section{REFERENCES}

1 Bhoori S, Rossi RE, Citterio D, et al. COVID-19 in long-term liver transplant patients: preliminary experience from an Italian transplant centre in Lombardy. Lancet Gastroenterol Hepatol 2020. doi:10.1016/ S2468-1253(20)30116-3. [Epub ahead of print: 09 Apr 2020].

2 Guan W-jie, Ni Z-yi, Hu Y, et al. Clinical characteristics of coronavirus disease 2019 in China. N Engl J Med 2020.

3 Ruscitti P, Cipriani P, Di Benedetto P, et al. Advances in immunopathogenesis of macrophage activation syndrome during rheumatic inflammatory diseases: toward new therapeutic targets? Expert Rev Clin Immunol 2017;13:1041-7.

4 Sawalha $\mathrm{AH}$, Zhao M, Coit P, et al. Epigenetic dysregulation of ACE2 and interferon-regulated genes might suggest increased COVID-19 susceptibility and severity in lupus patients. Clin Immunol 2020;215:108410.

5 de Wit E, van Doremalen N, Falzarano D, et al. Sars and MERS: recent insights into emerging coronaviruses. Nat Rev Microbiol 2016;14:523-34.

6 Yazdany J, Kim AHJ. Use of hydroxychloroquine and chloroquine during the COVID-19 pandemic: what every clinician should know. Ann Intern Med 2020. doi:10.7326/M20-1334. [Epub ahead of print: 31 Mar 2020].

7 Dörner T, Furie R. Novel paradigms in systemic lupus erythematosus. Lancet 2019;393:2344-58. 